\title{
Sustainable Water Management under Variable Rainfall Conditions in River Communities of Champhone District, Savannakhet Province, Lao PDR
}

\author{
Outhevy Vongmany ${ }^{1,3}$, Kazuo N. Watanabe ${ }^{1}$, Takeshi Mizunoya ${ }^{2}$, Makoto Kawase ${ }^{1}$, Akira Kikuchi ${ }^{1}$, Helmut \\ Yabar $^{2}$, Yoshiro Higano ${ }^{2}$, Nouansisavad Sombounsack ${ }^{3} \&$ Oukham Phounpakon $^{4}$ \\ ${ }^{1}$ Department of Bioindustrial Science, Faculty of Life and Environmental Sciences, University of Tsukuba, \\ Japan \\ ${ }^{2}$ Department of Sustainable Environmental Studies, Faculty of Life and Environmental Sciences, University of \\ Tsukuba, Japan \\ ${ }^{3}$ Faculty of Agriculture and Environment, University of Savannakhet, Lao PDR \\ ${ }^{4}$ Department of Natural Resources and Environment, Savannakhet Province, Lao PDR \\ Correspondence: Outhevy Vongmany, Department of Bioindustrial science, Faculty of Life and Environmental \\ Sciences, University Of Tsukuba, Japan. E-mail: outhevy@gmail.com
}

Received: February 26, $2018 \quad$ Accepted: March 28, $2018 \quad$ Online Published: May 30, 2018

doi:10.5539/jsd.v11n3p108 URL: https://doi.org/10.5539/jsd.v11n3p108

\begin{abstract}
A large majority of the rural population of Lao PDR remains dependent on agriculture for their livelihood and food security, for which access to and management of irrigated and rain-fed water sources is critical. Crop choices and planting calendars follow a monsoonal (dry season/wet season) weather system and are vulnerable to variations in the supply of rainfall, particularly deficits in the dry season and oversupply in the wet season. Climate change projections show that flood vulnerable areas like Champhone district, Savannakhet province might face worse problems in future, affecting food security and agricultural development.

This study examines how households are being affected by flooding and drought in Xe Champhone district. Flood vulnerability was assessed by calculating the rainfall variation to determine the water balance during rainy season and dry season. This was combined with analysis of social data from household surveys, together with institutional capacity at different levels and coping strategies currently used by farmers. Constraints and opportunities are identified to strengthen adaptive capacity and resilience to climate change in the Xe Champhone River basin of Savannakhet province. Hydrology data show that the water balance was unstable during both the rainy and dry seasons. The minimum runoff is very low in dry season $\left(\mathrm{Q}=2.4 \mathrm{~m}^{3} / \mathrm{sec}\right)$, while the maximum runoff is high in rainy season $\left(\mathrm{Q}=274 \mathrm{~m}^{3} / \mathrm{sec}\right)$. Harvesting rainwater in the wet season for use in dry season could reduce the vulnerability of farmers. This study aims to support small-scale community water management initiatives in Lao PDR.
\end{abstract}

Keywords: rainfall variability, vulnerability, community water management, climate change adaptation, river, rice production, Lao PDR

\section{Background}

Globally, the rainfall patterns that farmers depend on are being increasingly disrupted by climate change, requiring new coping strategies. Rice production is facing challenges such as water shortages, flooding and other factors that limit the capacity of farmers to grow their crops (e.g.,Tao et al., 2007; Peng et al., 2004). As the main food crop of Asia, the vulnerability of rice production to climate change has therefore become of key concern xboth currently and also for the future food security of the region. The Lao People's Democratic Republic (Laos) is highly challenged by this situation because of the combination of low state capacity to respond (including technical knowledge and budget) and lack of systems to predict or control drought or flood.

A large majority of the rural population of Laos remains dependent on agriculture for livelihoods and food security, for which access to and management of both irrigated and rain-fed water sources is critical. Crop choices and planting calendars follow a monsoonal (dry season/wet season) weather system, and are very 
vulnerable to variations in the supply of rainfall, particularly deficits in the dry season and oversupply in the wet season. Economic development and population growth in Laos will require increases in agricultural output to support human consumption, and farm technologies and cultivar breeding supporting rice farming will face challenges beyond the farm level to ensure and increase rice production for future climate change conditions (Boulidam, 2012).The lack of solutions to both flood and drought limits agricultural development in the central and southern part of Laos, where Savannakhet province is located, which contains the largest area of paddy cultivation in the country, covering 194,157 hectares or more than 20 percent of Laos' total paddy land (DOA, 2009).Several modeling studies have been carried out in Laos, including simulation of climate change impacts on lowland paddy rice production potential in Savannakhet Province (IPCC, 2007), and projections from the International Panel on Climate Change (IPCC, 2014)show that flood-vulnerable areas like Savannakhet Province might face increasing problems in the future. IPCC's Fifth Assessment Report (AR5) forecasts an enhanced hydrological cycle and an increase in area-averaged annual mean rainfall over Asia, while working Group II of AR5 also projected that higher rainfall intensity, particularly during the summer monsoon, could increase flood-prone areas in temperate and tropical Asia (Hijioka, et al., 2014).

The local population in Champhone district, Savannakhet province consists mainly of rural farming households, with rice as their most important food crop, which also provides income for some families. These communities rely on the local Xe Champhone River to irrigaterice paddies during rainy season, but as is the case in many locations of Laos, when the water level is too high,substantial damage to crops can result A recent flood assessment of 10, 20 and 50-year return periods in Champhone district found a large area to be highly vulnerable to flooding at depths of greater than $6 \mathrm{~m}$ (Hazaraki et al. 2008).After floods, people often lack sufficient stocks of food to maintain household consumption, forcing them to change from consuming own production and selling surplus to buying from other areas to continue accessing food.Local livelihoodsand food security are therefore highly vulnerable to flood impacts, while in the dry season, the same communities often lackenough water fora second crop of rice or other dry season crops.Lack of access to irrigation heightens water stress faced by farmers during the dry season and otherwise limits the ability of farmers to manage their water supply. A recentclimate change adaptation project in Champhone districtemphasized the need to develop irrigation, though was only able to expand1000m of irrigation canal due to limited budget (MRC, 2014). This highlights the importance of local water storage methods and tools to retain water from periods of heavy rainfall to use in drierperiods, in order to manage variability and support local communitiesin terms of food security and income. The high costs of infrastructure such as irrigation canalsmean that these methods and tools have to be based on local capacity and pay particular attention to their feasibility within economic constraints.Instead of waiting for budget to manage water supply by irrigation methods, other countries facing similar problems (e.g. Nepal, Kattel,2007) have tried community-based water management methods to seek ways to store water,though these approaches can also be expensive - one aim of this study is to findfeasible solutions for water management that will be appropriate to local conditions.

This research was designed to understand in the study locations (see next section) the impacts of rainfall variability, and draw on the experiences of community members to identify ways to protect their water supply against climate variability through storage methods, as well as how to adapt crop types. The study focuses on the possibility of community and household-based water management in the context of the resources and capacity available in Champhone District, Savannakhet Province, with the following objectives:

- To assess impacts of climate change, especially rainfall variability, on crop production patterns along the Xe Champhone River.

- To identify community capacity to protect their water supply against rainfall variability through storage methods, and also to understand how to adapt crop types.

- To recommend adaptation options to safeguard local food security and livelihoods. 


\section{Materials and Methods}

\subsection{Description of the Study Area}

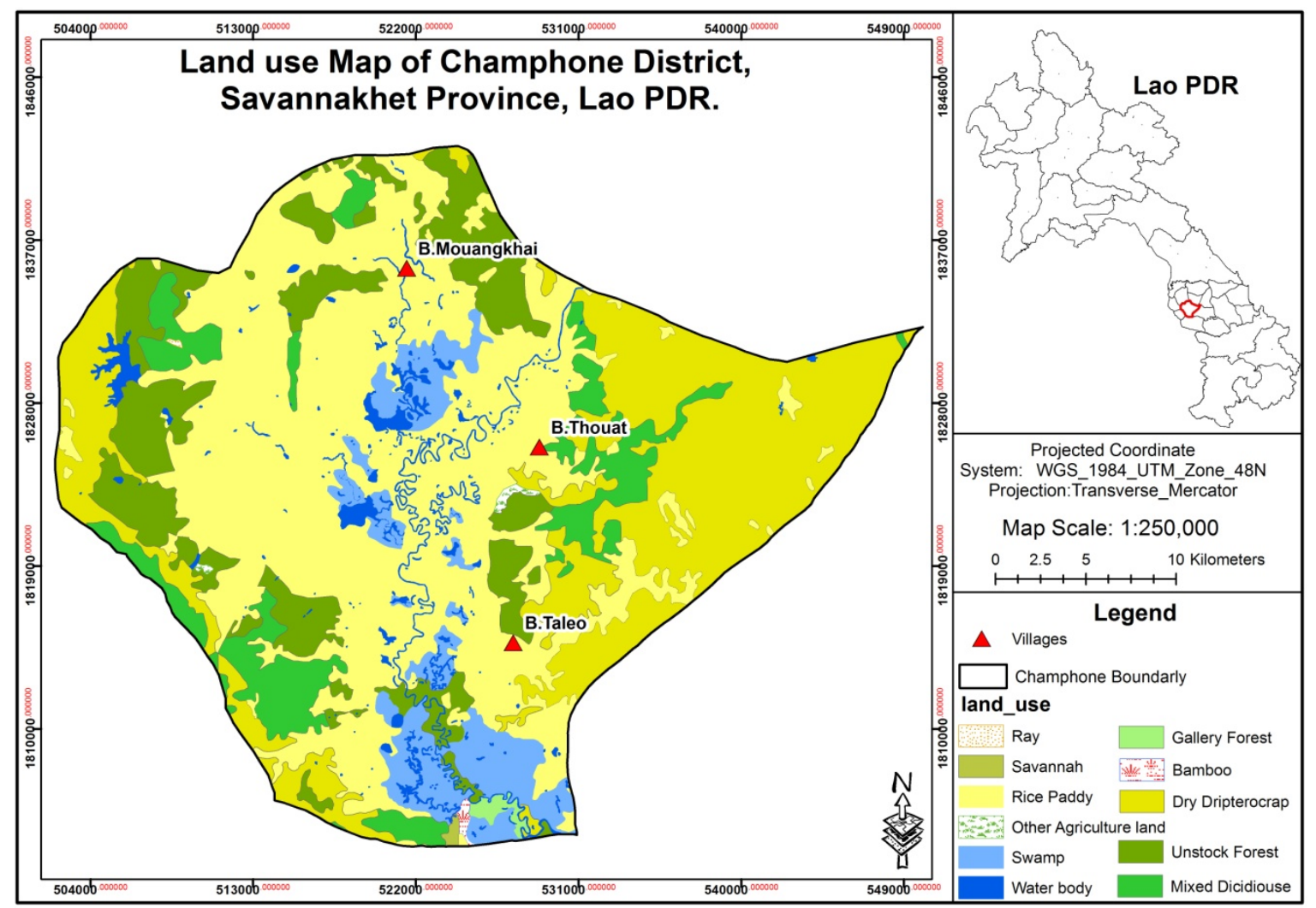

Figure 1. Map of study areas in Champhone District of Savannakhet Province, Lao PDR

The study focused on the three villages of Mouangkhai, Thouat and Taleo in Champhone District of Savannakhet Province, Laos (Figure 1). The three villages are located on the low-lying floodplain in upstream, middle and downstream areas of the Xe Champhone river, and are characterized by high flood vulnerability (Hazarika et al., 2008). The elevation of the area is 94 to $227 \mathrm{~m}$ above sea level, and features a wide area of paddy land, swamps and limited areas of forest. The total area of Champhone District is 102,984 ha, with agriculture covering 93.61\% of the area.

\subsection{Respondents of the Study}

Survey interviews were conducted based on the priority areas affected by flooding for sampling from the 3 villages. Respondents were considered because of their agriculture land near the Xe Champhone being vulnerable to damage from the flooding. To characterize social and economic drivers of flood vulnerability in the study locations, household interviews were conducted during the dry season based on the availability of farmers, using a structured questionnaire with respondents located near and along the riverbanks in the 3 villages of Mouangkhai, Thouat and Taleo. Focus Group Discussions (FGDs) were also conducted at the local level, with follow-up group FGDs after the rainy season to understand issues faced by the farmers through the planting cycle.

\subsection{Secondary Data}

Documents were also sourced from the concerned institutions of the Lao government. Historical weather data for 1995-2015 were obtained from the Provincial Meteorology Station Office (PMS) of Savannakhet. River information of the district came from the Department of Natural Resources and Environment in the provincial capital of Savannakhet. Water discharge was analyzed using the Bradshaw Model (Bradshaw et al., 1978). 


\section{Results and Discussion}

\subsection{Hydrological Analysis}

\subsubsection{Monthly Rainfall}

Table 1. Flood records of the Xe Champhone River from 1988-2015 (Zero of Gauge from Mean Sea Level:130.378m (MSL))

\begin{tabular}{|c|c|c|c|c|c|}
\hline No. & Year & $\begin{array}{c}\text { Maximum } \\
\text { Gauge Height }\end{array}$ & $\begin{array}{c}\text { Date } \\
\text { observed }\end{array}$ & $\begin{array}{c}\text { Maximum } \\
\text { Gauge height reading } \\
\text { from MSL }\end{array}$ & Remark \\
\hline 1 & 1988 & 8.12 & 5-Aug & 138.498 & Flood + Drought \\
\hline 2 & 1989 & 6.75 & 25-JuL & 137.128 & \\
\hline 3 & 1990 & 7.85 & 1-Sep & 138.228 & Flood \\
\hline 4 & 1991 & 8.57 & 20-Aug & 138.948 & Flood \\
\hline 5 & 1992 & 7.26 & 6-Sep & 137.638 & \\
\hline 6 & 1993 & 6.54 & 10-Aug & 136.918 & \\
\hline 7 & 1994 & 7.56 & 31-Aug & 137.938 & \\
\hline 8 & 1995 & 7.81 & 1-Sep & 138.188 & Flood \\
\hline 9 & 1996 & 10.15 & 18-28-Sep & 140.528 & Severe flood \\
\hline 10 & 1997 & 8.27 & 18-Aug & 138.648 & Flood \\
\hline 11 & 1998 & 7.47 & 17-Sep & 137.848 & \\
\hline 12 & 1999 & 7.80 & 27- July & 138.158 & \\
\hline 13 & 2000 & 8.37 & 12-16 Sep & 138.448 & Flood \\
\hline 14 & 2001 & 8.13 & 12- 13 Aug & 138.508 & Flood \\
\hline 15 & 2002 & 7.70 & 1-Aug & 138.078 & \\
\hline 16 & 2003 & 7.83 & 14-Sep & 138.208 & \\
\hline 17 & 2004 & 8.04 & 11-12 Sep & 138.418 & Flood \\
\hline 18 & 2005 & 8.52 & 11-15 Sep & 138.898 & Flood (2 occasions) \\
\hline 19 & 2006 & 7.72 & 17-Aug & 138.098 & \\
\hline 20 & 2007 & 8.20 & 6-11 Oct & 138.578 & Flood \\
\hline 21 & 2008 & 7.72 & 22-Sep & 138.098 & \\
\hline 22 & 2009 & 7.86 & 12-14-Aug & 138.238 & \\
\hline 23 & 2010 & 7.93 & 29-31-Aug & 138.308 & Flood \\
\hline 24 & 2011 & 8.76 & 08- 14 Aug & 139.138 & \\
\hline 25 & 2012 & 8.04 & 04-07 July & 138.418 & Flood \\
\hline 26 & 2013 & 8.00 & $23 \mathrm{Sept}$ & 138.378 & \\
\hline 27 & 2014 & 8.24 & 6 August & 138.618 & \\
\hline 28 & 2015 & 8.07 & $4 \mathrm{Sept}$ & 138.448 & Flood \\
\hline
\end{tabular}

Remark: The historical maximum flood level in the Xe Champhone was recorded at11.26m or 141.638MSL, and occurred on 17/8/1978, lasting 28 days.

Flood records of the Xe Champhone river in table 1 show the frequency of flooding during the rainy season, often peaking in the statistics during August-September, while in the dry season from December to May the area can become very dry. Table 1 also shows how often near-flood conditions are reached in the Xe Champhone, highlighting the vulnerability of local farmers. According to a key informant interview with the head of the 
Provincial Department of Environment, the overall observed trend is towards higher frequency of extreme events and increased rainfall intensity, while the total rainfall and number of wet days has decreased.



Figure 2. Variation of rainfall in Savannakhet Province from 1995-2015

Figure 2 shows a downward trend in the frequency of maximum 24-hour rainfall above $150 \mathrm{~mm} /$ day after 2003, but higher overall variation compared with beforehand. IPCC research projects an increase in extreme rainfall events (IPCC, 2014), which could generate further flooding at the study sites.

Table 2. Water discharge in the dry season and rainy season at Xe Champhone station

\begin{tabular}{|c|c|c|c|c|c|c|c|c|c|c|c|c|}
\hline \multicolumn{7}{|c|}{ Dry season minimum $Q$ in $\left(\mathbf{m}^{3} / \mathbf{s e c}\right)$} & \multicolumn{6}{|c|}{ Rainy season maximum $Q$ in $\left(\mathrm{m}^{3} / \mathrm{sec}\right)$} \\
\hline \multicolumn{7}{|c|}{ Xe Champhone at M. Kengkok } & \multicolumn{6}{|c|}{ Xe Champhone at M. Kengkok } \\
\hline Year & Jan & Feb & Mar & Apr & Nov & Dec & May & Jun & July & Aug & Sep & Oct \\
\hline 1995 & 3.859 & 2.897 & 1.99 & 1.252 & 5.629 & 21.052 & 27.654 & 209.413 & 425.283 & 452.148 & 468.409 & 28.271 \\
\hline 1996 & 3.415 & 1.334 & 1.829 & 1.318 & 6.342 & 4.092 & 62.134 & 63.057 & 266.894 & 438.613 & 803.607 & 318.725 \\
\hline 1997 & 2.897 & 2.073 & 1.252 & 0.685 & 4.331 & 1.829 & 35.851 & 193.688 & 391.128 & 524.242 & 377.413 & 29.525 \\
\hline 1998 & 5.492 & 4.21 & 3.523 & 3.099 & 0.637 & 0.176 & 3.099 & 28.271 & 18.966 & 66.815 & 422.882 & 20.257 \\
\hline 1999 & 8.395 & 1.527 & 0.837 & 0.505 & 9.084 & 11.711 & 80.303 & 196.948 & 477.284 & 459.617 & 436.174 & 52.013 \\
\hline 2000 & 13.149 & 5.089 & 3.745 & 2.702 & 6.196 & 2.997 & 160.367 & 385.384 & 501.793 & 357.3 & 536.326 & 102.562 \\
\hline 2001 & 6.052 & 5.629 & 6.342 & 7.732 & 4.702 & 3.523 & 19.735 & 444.74 & 443.511 & 509.66 & 438.613 & 24.097 \\
\hline 2002 & 3.859 & 3.859 & 3.745 & 6.943 & 7.412 & 5.222 & 124.921 & 439.835 & 459.617 & 453.388 & 422.882 & 39.427 \\
\hline 2003 & 3.859 & 3.415 & 2.799 & 2.422 & 5.492 & 4.261 & 41.279 & 143.834 & 51.593 & 396.915 & 469.672 & 35.851 \\
\hline 2004 & 3.099 & 3.633 & 2.997 & 2.073 & 3.633 & 2.607 & 22.688 & 20.785 & 416.908 & 465.889 & 495.284 & 54.567 \\
\hline 2005 & 0 & 0 & 0 & 0 & 0 & 0 & 0 & 340.959 & 492.045 & 511.637 & 560.907 & 271.678 \\
\hline 2006 & 0 & 0 & 0 & 0 & 0 & 0 & 0 & 0 & 428.898 & 453.388 & 201.888 & 453.388 \\
\hline
\end{tabular}




\begin{tabular}{|c|c|c|c|c|c|c|c|c|c|c|c|c|}
\hline 2007 & 0 & 0 & 0 & 0 & 0 & 0 & 0 & 83.468 & 318.725 & 407.438 & 316.646 & 514.939 \\
\hline 2008 & 0 & 0 & 0 & 0 & 0 & 0 & 0 & 344.197 & 156.697 & 436.174 & 455.875 & 0 \\
\hline 2009 & 0 & 0 & 0 & 0 & 0 & 0 & 284.315 & 109.16 & 332.4 & 473.47 & 46.69 & 274.569 \\
\hline 2010 & 0.018 & 0.022 & 0.027 & 0 & 3.415 & 2.158 & 131.523 & 38.336 & 241.795 & 482.393 & 472.836 & 472.836 \\
\hline 2011 & 3.308 & 1.334 & 4.21 & 2.158 & 4.27 & 1.908 & 75.669 & 74.407 & 419.89 & 593.827 & 482.393 & 281.374 \\
\hline 2012 & 1.318 & 1.285 & 1.125 & 0.376 & 0.685 & 0.13 & 26.143 & 488.173 & 496.582 & 135.226 & 417.504 & 12.939 \\
\hline 2013 & 0.141 & 0.152 & 0.228 & 0.287 & 0.465 & 0.526 & 16.989 & 94.179 & 392.86 & 374.023 & 491.399 & 344.738 \\
\hline 2014 & 0.734 & 0.371 & 0.176 & 0.13 & 0.548 & 0.685 & 0.837 & 199.822 & 486.242 & 522.242 & 342.036 & 94.179 \\
\hline 2015 & 0.637 & 0.592 & 0.214 & 0.02 & 10.544 & 4.639 & 0.919 & 203.964 & 397.496 & 367.846 & 499.836 & 277.961 \\
\hline \multirow{2}{*}{ Mean } & 2.868 & 1.782 & 1.669 & 1.51 & 3.495 & 3.215 & 53.1 & 195.4 & 362.7 & 423 & 436.2 & 176.4 \\
\hline & \multicolumn{6}{|c|}{2.4} & \multicolumn{6}{|c|}{274} \\
\hline
\end{tabular}

The higher overall variation rainfall (figure 2), in combination with the high maximum daily water height of the river, suggests occurrence of flooding. Similar observations also occurred in August in 1995, 2005, 2006 and 2012. This indicates that flooding is likely to occur in August as well as in July, which would initially bring irrigation water for rice farms along the river on the floodplain. This is supported by the difference of discharge amount during the dry season and rainy season (Table 2), showing the water balance in Champhone station: while the minimum runoff is very low in dry season $\left(\mathrm{Q}=2.4 \mathrm{~m}^{3} / \mathrm{sec}\right)$, the maximum runoff is high in rainy season $\left(\mathrm{Q}=274 \mathrm{~m}^{3} / \mathrm{sec}\right)$.

\subsubsection{Maximum and Highest Minimum Daily Water Level of Xe Champhone River}

In 2011, severe flooding occurred in August and September when the differences between maximum and highest daily minimum water depths of the Xe Champhone were low. Similar phenomena occurred in 2005 and 1997 (Table 3). This suggests that the river overflowed its banks and inundated the floodplain. Similar events happened in the month of August in 2004 and 2001, indicating that flooding occurred. The severe lower values, particularly when this does not measure a minimum water level indicates that drought occurred during the dry season.

Table 3. Maximum and highest minimum daily water level of Xe Champhone River

\begin{tabular}{|c|c|c|c|c|}
\hline \multirow{2}{*}{ Year } & \multicolumn{2}{|c|}{ Maximum of Water level } & \multicolumn{2}{|c|}{ Minimum of water level } \\
\hline & Gauge & MSL & Gauge & MSL \\
\hline 1995 & 7.82 & 138.198 & 0.74 & 131.118 \\
\hline 1996 & 10.12 & 140.498 & 0.79 & 131.168 \\
\hline 1997 & 8.25 & 138.628 & 0.68 & 131.058 \\
\hline 1998 & 7.45 & 137.828 & 0.04 & 130.418 \\
\hline 1999 & 7.89 & 138.268 & 0.53 & 130.908 \\
\hline 2000 & 8.34 & 138.718 & 0.90 & 131.278 \\
\hline 2001 & 8.14 & 138.518 & 1.04 & 131.418 \\
\hline 2002 & 7.75 & 138.128 & 1.06 & 131.438 \\
\hline 2003 & 7.83 & 138.208 & 0.93 & 131.308 \\
\hline 2004 & 8.03 & 138.408 & 0.85 & 131.228 \\
\hline 2005 & 8.52 & 138.898 & 0.00 & 130.378 \\
\hline 2006 & 7.70 & 138.078 & 0.00 & 130.378 \\
\hline 2007 & 8.18 & 138.558 & 0.00 & 130.378 \\
\hline 2008 & 7.72 & 138.098 & 0.00 & 130.378 \\
\hline 2009 & 7.86 & 138.238 & 0.00 & 130.378 \\
\hline
\end{tabular}




\begin{tabular}{ccccc}
\hline 2010 & 7.93 & 138.308 & 0.30 & 130.678 \\
2011 & 8.76 & 139.133 & 0.87 & 131.248 \\
2012 & 8.04 & 138.418 & 0.52 & 130.898 \\
2013 & 8.00 & 138.378 & 0.53 & 130.903 \\
2014 & 8.24 & 138.613 & 0.51 & 130.883 \\
2015 & 8.07 & 138.443 & 2.43 & 132.808 \\
Average & 8.13 & 138.50 & 0.61 & 130.98 \\
Max & $\mathbf{1 0 . 1 2}$ & 140.50 & 2.43 & 132.81 \\
Min & 7.45 & 137.83 & $\mathbf{0 . 0 0}$ & 130.38 \\
\hline
\end{tabular}

\subsection{Projected Rice Security}

Table 4. Projected rice security with and without severe flood at the district scale

\begin{tabular}{|c|c|c|c|c|c|c|c|c|}
\hline \multirow[b]{2}{*}{ Year } & \multirow[b]{2}{*}{$\begin{array}{c}\text { (1) } \\
\text { Population }\end{array}$} & \multirow[b]{2}{*}{$\begin{array}{c}\text { Rice } \\
\text { Consumption } \\
\text { (Ton) }\end{array}$} & \multicolumn{4}{|c|}{ WITHOUT FLOODING } & \multicolumn{2}{|c|}{ WITH FLOODING } \\
\hline & & & $\begin{array}{l}\text { (3) Rice } \\
\text { Production } \\
\text { (Ton) }\end{array}$ & $\begin{array}{c}\text { (4) } \\
\text { Available } \\
\text { Rice for } \\
\text { cash (Ton) }\end{array}$ & $\begin{array}{c}(5) \\
\text { Income } \\
\text { from Rice } \\
\text { (USD) }\end{array}$ & $\begin{array}{c}\text { (6) } \\
\text { Income per } \\
\text { Month } \\
\text { (USD) }\end{array}$ & $\begin{array}{c}\text { (7) } \\
\text { Rice } \\
\text { Production }\end{array}$ & $\begin{array}{c}(8) \\
\text { Rice } \\
\text { Deficit } \\
\text { (Ton) }\end{array}$ \\
\hline 2016 & 111970 & 36390.3 & $77,103.0$ & $40,712.8$ & $10,178.2$ & 848.182 & $52,430.0$ & $16,039.8$ \\
\hline 2017 & 114209 & 37118.1 & $77,103.0$ & $39,984.9$ & $9,996.2$ & 833.020 & $52,430.0$ & $15,312.0$ \\
\hline 2018 & 116494 & 37860.4 & $77,103.0$ & $39,242.6$ & $9,810.6$ & 817.554 & $52,430.0$ & $14,569.6$ \\
\hline 2019 & 118823 & 38617.6 & $77,103.0$ & $38,485.4$ & $9,621.3$ & 801.779 & $52,430.0$ & $13,812.4$ \\
\hline 2020 & 121200 & 39390.0 & $77,103.0$ & $37,713.0$ & $9,428.3$ & 785.688 & $52,430.0$ & $13,040.1$ \\
\hline 2025 & 133815 & 43489.7 & $77,103.0$ & $33,613.3$ & $8,403.3$ & 700.277 & $52,430.0$ & $8,940.3$ \\
\hline 2030 & 147742 & 48016.2 & $77,103.0$ & $29,086.8$ & $7,271.7$ & 605.976 & $52,430.0$ & $4,413.9$ \\
\hline 2034 & 159921 & 51974.2 & $77,103.0$ & $25,128.8$ & $6,282.2$ & 523.516 & $52,430.0$ & 455.8 \\
\hline 2035 & 163119 & 53013.7 & $77,103.0$ & $24,089.3$ & $6,022.3$ & 501.860 & $52,430.0$ & $(583.7)$ \\
\hline 2040 & 180097 & 58531.4 & $77,103.0$ & $18,571.6$ & $4,642.9$ & 386.908 & $52,430.0$ & $(6,101.4)$ \\
\hline 2045 & 198841 & 64623.4 & $77,103.0$ & $12,479.6$ & $3,119.9$ & 259.991 & $52,430.0$ & $(12,193.4)$ \\
\hline 2050 & 219537 & 71349.5 & $77,103.0$ & $5,753.5$ & $1,438.4$ & 119.865 & $52,430.0$ & $(18,919.5)$ \\
\hline 2053 & 232974 & 75716.7 & $77,103.0$ & $1,386.3$ & 346.6 & 28.882 & $52,430.0$ & $(23,286.6)$ \\
\hline 2054 & 237634 & 77231.0 & $77,103.0$ & $(128.0)$ & $(32.0)$ & $(2.666)$ & $52,430.0$ & $(24,800.9)$ \\
\hline 2055 & 242386 & 78775.6 & $77,103.0$ & $(1,672.6)$ & $(418.2)$ & $(34.846)$ & $52,430.0$ & $(26,345.6)$ \\
\hline 2060 & 267614 & 86974.6 & $77,103.0$ & $(9,871.6)$ & $(2,467.9)$ & (205.659) & $52,430.0$ & $(34,544.6)$ \\
\hline 2070 & 326220 & 106021.6 & $77,103.0$ & $(28,918.6)$ & $(7,229.6)$ & $(602.471)$ & $52,430.0$ & $(53,591.6)$ \\
\hline 2080 & 397661 & 129239.7 & $77,103.0$ & $(52,136.7)$ & $(13,034.2)$ & $(1,086.182)$ & $52,430.0$ & $(76,809.7)$ \\
\hline 2085 & 439050 & 142691.1 & $77,103.0$ & $(65,588.1)$ & $(16,397.0)$ & $(1,366.419)$ & $52,430.0$ & $(90,261.1)$ \\
\hline 2086 & 447831 & 145544.9 & $77,103.0$ & $(68,441.9)$ & $(17,110.5)$ & $(1,425.873)$ & $52,430.0$ & $(93,114.9)$ \\
\hline 2087 & 456787 & 148455.8 & $77,103.0$ & $(71,352.8)$ & $(17,838.2)$ & $(1,486.517)$ & $52,430.0$ & $(96,025.8)$ \\
\hline 2090 & 484746 & 157542.5 & $77,103.0$ & $(80,439.5)$ & $(20,109.9)$ & $(1,675.823)$ & $52,430.0$ & $(105,112.5)$ \\
\hline 2100 & 590903 & 192043.4 & $77,103.0$ & $(114,940.4)$ & $(28,735.1)$ & $(2,394.592)$ & $52,430.0$ & $(139,613.4)$ \\
\hline
\end{tabular}

[1] Population growth rate $=2.1 \%$

[2] Rice consumption $=0.36 *$ Population 
[3] Rice production without severe flood $=3$ ton/ha* Rice area

[4] Excess rice for cash $=$ Rice production - Rice consumption

[5] Income from rice $=$ Excess rice (ton) $* 200 \mathrm{USD} /$ ton

[6] Income per month/household= Income from rice/ Number of Household

[7] Rice production during severe flood= production without flood $-32 \%$ (Production without severe flood)

[8] Rice deficit for rice consumption

Rice production in the study location is unstable because of the clear risk of both flooding and drought, as depicted in the historical data above, and which is likely to increase with climate change (MRC, 2010). Without climate change disturbances, especially the increasing heavy rainfall events that cause flooding, households could produce enough rice for their own consumption with surplus for sale. In the flooded conditions to which the study sites are very vulnerable however, the households cannot produce sufficient harvests. Moreover, the communities lack adaptive capacity to severe flooding along social and economic dimensions, and as a consequence need to secure rice from other areas during such events. The projected climate conditions would also increase the vulnerability of these communities with the increasing population and hence demand for rice.

Utilizing the household dataset even with the basic replacement level population growth rate of $2.1 \%$ (likely below the real figure), projected periods with a secure rice supply in non-flooded conditions varies among villages. Households could maintain rice security for longer periods of time, but this depends mainly on whether rice remains the main source of cash income. If the communities experience severe flooding with $32 \%$ damage to the wet season rice crop from the average damage in household interview estimations, households have to find cash income from non-rice sources or otherwise sell rice for household consumption, which they must then purchase later.

\subsection{Livelihood Analysis}

3.3.1 Crop Calendar



Rain season
Dry season
Heavy rain(flood risk)
No water

Figure 3. Crop calendar of the study sites

Figure 3 shows the sequencing of rice growing activities during the crop calendar. 
After preparing the land, farmers start to plow rice in the beginning of the rainy season whenever there is enough water, without knowing potential weather conditions for the year, in terms of if flooding is likely or not. This means that panic harvesting is common during flood conditions; while in the dry season farmers have no water for growing a second rice crop (which could mitigate losses in flood years).

\subsubsection{Sensitivity of the Rice Production System}

Figure 3 highlights the sensitivity of the rice production system to flooding events at various stages of the wet season cropping period. Rain starts at the end of May and is heaviest from June to August, with the most severe flooding from August to October (Figure 3).During November to May, most farmers cannot grow a dry season rice crop due to lack of water supply. The sensitivity of rainfed rice systems to climatic risks is hence high at most stages of the cropping season. A majority of the respondents in the household survey did not want to change their rice cropping period unless an irrigation project is developed to reduce flood damage to their crops. With short maturing varieties and an irrigation project, the communities could reduce, if not avoid, flooding damages.

\subsubsection{Adaptation in Rice Production Systems}

Household interviews identified the present level of adaptation in rice production systems based on responses about rice replanting, pumping irrigation water from the river, use of short maturing rice varieties and development of irrigation systems. Just under $4 \%$ of respondents from the three villages could replant after flooding (Table 5), while over 93\% could not replant. Few respondents observed that their crops can recover after flooding, depending on the degree of damage, while many said their rice fields were destroyed by flooding. One respondent had decided not to plant rice during the rainy season due to flood damage during the previous several years. Meanwhile, $99.5 \%$ of respondents said they were unable to change the rice planting date to respond to changing weather conditions. This was because they are unable to predict rainfall frequency over the year, and cannot plant early if there is insufficient water. Therefore, farmers begin plowing rice whenever there is enough available water. This highlights the very narrow boundaries of adaptation that farmers work within in terms of the planting cycle, and the need for state support in terms of information and alternative techniques.

Table 5. Respondents adapted on flooding in the study site

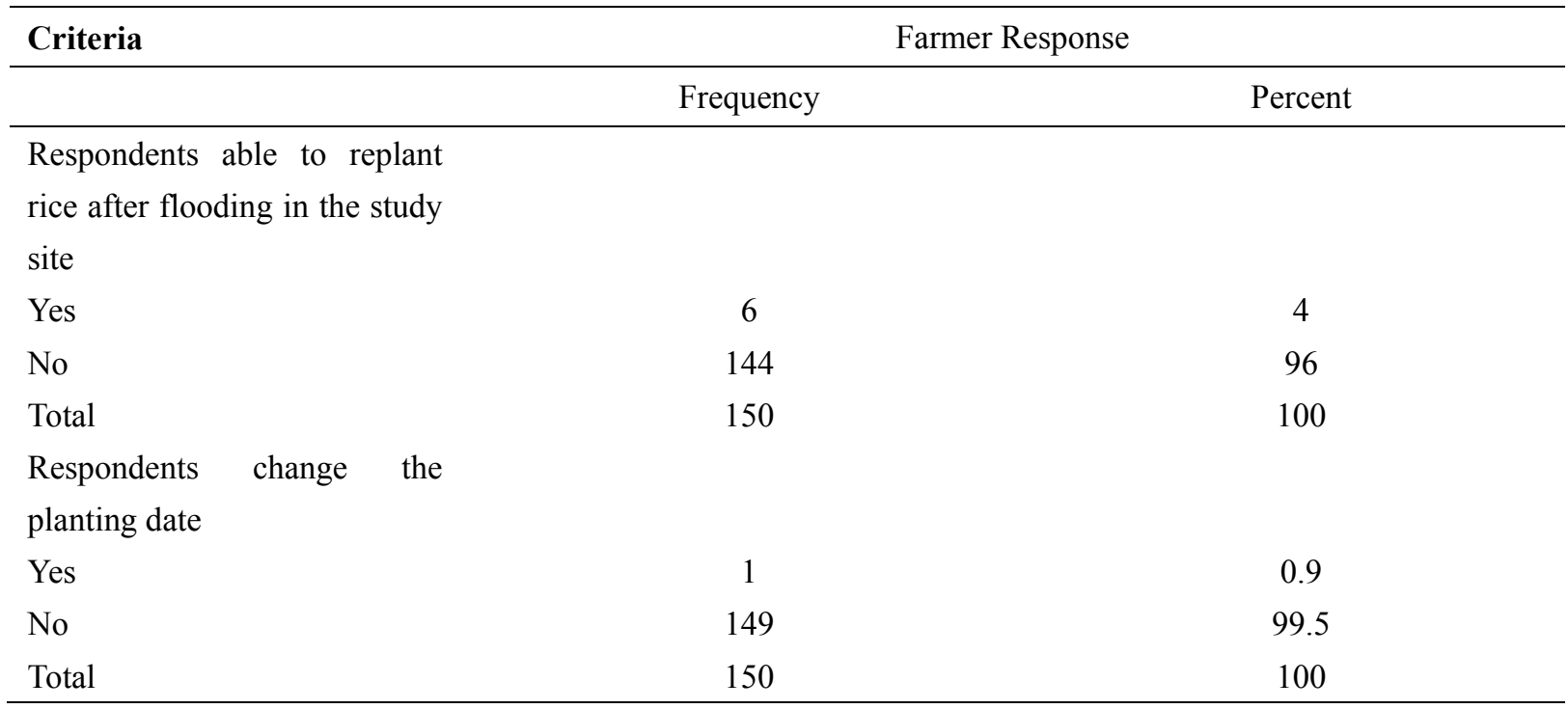

According to the respondents, the commonly used Thasano and Thadokham rice varieties are not short maturing, taking 135-145 days with a height of 95-115 cm. The respondents also stated that short maturing varieties that can be direct seeded to reduce exposure to flooding have not yet been introduced in the area. Based on interviews, a project aimed to expand the irrigation system in Thouat, but has not yet been implemented and the people continue to wait. Overall awareness of plans for irrigation to secure rice production remains low, while wet season production is insufficient according to the respondents. 
3.3.4 Correlation between Rice Production and Social Sensitivity Factors

Table 6. Correlation between rice production and socio-economic factors

\begin{tabular}{|c|c|c|c|c|c|c|c|c|c|c|c|}
\hline Various & $\begin{array}{l}\text { Number of } \\
\text { Household }\end{array}$ & Age & Gender & Education & ccupation & $\begin{array}{c}\mathrm{HH} \\
\text { income }\end{array}$ & $\begin{array}{l}\text { Rice } \\
\text { size }\end{array}$ & $\begin{array}{r}\text { Rice } \\
\text { Variety }\end{array}$ & $\begin{array}{l}\text { Have } \\
\text { fish } \\
\text { pond }\end{array}$ & $\begin{array}{c}\text { Source of } \\
\text { emergency } \\
\text { money }\end{array}$ & $\begin{array}{c}\text { Rice } \\
\text { Production }\end{array}$ \\
\hline $\begin{array}{l}\text { Number of } \\
\text { Household }\end{array}$ & 1 & $.092^{\mathrm{ns}}$ & $-.058^{\mathrm{ns}}$ & $-.045^{\mathrm{ns}}$ & $.183^{*}$ & $.168^{*}$ & $.085^{\mathrm{ns}}$ & $-.020^{\mathrm{ns}}$ & $-.105^{\mathrm{ns}}$ & $.306^{* *}$ & $.181^{*}$ \\
\hline Age & & 1 & $-.018^{\mathrm{ns}}$ & $-.214^{* *}$ & $.209^{* *}$ & $.110^{\mathrm{ns}}$ & $-.022^{\mathrm{ns}}$ & $.029^{\mathrm{ns}}$ & $-.012^{\mathrm{ns}}$ & $-.060^{\mathrm{ns}}$ & $.067^{\mathrm{ns}}$ \\
\hline Gender & & & 1 & $.238 * *$ & $-.019^{\text {ns }}$ & $.138^{\mathrm{ns}}$ & $.141^{\mathrm{ns}}$ & $-.133^{\mathrm{ns}}$ & $-.153^{\mathrm{ns}}$ & $.146^{\mathrm{ns}}$ & $.232^{* *}$ \\
\hline Education & & & & 1 & $.242 * *$ & $.438 * *$ & $.128^{\mathrm{ns}}$ & $-.215^{\mathrm{ns}}$ & $-.176^{*}$ & $-.047^{\mathrm{ns}}$ & $.134^{\mathrm{ns}}$ \\
\hline Occupation & & & & & 1 & $.372 * *$ & $.029^{\mathrm{ns}}$ & $-.130^{\mathrm{ns}}$ & $-.082^{\text {ns }}$ & $.131^{\mathrm{ns}}$ & $.201^{*}$ \\
\hline $\mathrm{HH}$ income & & & & & & 1 & $.152^{\mathrm{ns}}$ & $-.099^{\text {ns }}$ & $-.143^{\mathrm{ns}}$ & $.003^{\mathrm{ns}}$ & $.274 * *$ \\
\hline Rice size & & & & & & & 1 & $-.232^{\mathrm{ns}}$ & $-.208 *$ & $.164^{\mathrm{ns}}$ & $.499 * *$ \\
\hline Rice Variety & & & & & & & & 1 & $.089^{\mathrm{ns}}$ & $-.150^{\mathrm{ns}}$ & $-.193^{\mathrm{ns}}$ \\
\hline $\begin{array}{l}\text { Have fish } \\
\text { pond }\end{array}$ & & & & & & & & & 1 & $-.313 * *$ & $-.432 * *$ \\
\hline $\begin{array}{l}\text { Source of } \\
\text { emergency }\end{array}$ & & & & & & & & & & 1 & $.330 * *$ \\
\hline money & & & & & & & & & & & \\
\hline $\begin{array}{l}\text { Rice } \\
\text { Production }\end{array}$ & & & & & & & & & & & 1 \\
\hline
\end{tabular}

ns. Not significant*. Significant at the 0.05 level **. Significant at the 0.01 level

Rice production has significant correlation with household income and farm size ( $\mathrm{P}<0.01)$ (Table 6), as well as the number of household members, their education and age. This in agreement with other studies such as Bornales (2004) in Mt. Malindang, Philippines, in that those with higher income can afford to purchase farm inputs to enhance rice production, coupled with using greater experience in maximizing yields. Adaptation that is specific to social factors such as gender, age, health, social status, ethnicity, and class could reduce vulnerability to impacts of climate change (Smit et al., (2001); Adger et al., (2009)).

\subsubsection{Economic Sensitivity}

Table 7. Rice farm profile in the three villages

\section{Criteria}

\section{Occupation}

Rice farmer

Government official

Worker

Retired

Other

Total

Income

.00

7-186.9
Farmer Response

Frequency Percent

\begin{tabular}{cc}
130 & 84.4 \\
14 & 9.1 \\
3 & 1.9 \\
4 & 2.6 \\
3 & 1.9 \\
154 & 100.0 \\
& \\
7 & 4.7 \\
113 & 75.8 \\
\hline
\end{tabular}


187-373.9

374-559.9

Total

16

13

149

149

2

2

153

146

8

154

53

101
10.7

8.7

100.0

97.4

1.3

1.3

100.0

94.8

100.0

100.0

The respondents in the three villages are generally small-holder farmers who additionally raised livestock in their backyards (Table 7). Incomes are predominantly very low, although a few households have greater earnings by trading, owning shops or raising relatively larger herds of livestock.

\subsubsection{Economic Adaptation}

Sources of money for labor and in times of need, and participation in fishing livelihoods to diversify income and food sources were utilized to identify the households' ability to adapt economically. The respondents generally have weak economic adaptation strategies, borrowing money for hired farm labor at $10 \%$ interest to be paid at the end of the harvest. The households also undertook distress sales of poultry and livestock in times of need. Younger members of the family worked as hired labor outside their village, and even as far as neighboring Thailand to support family income. Labor borrowing against an unpredictable rice harvest highlights the high economic sensitivity of communities which depend mainly on rice production for household food supply and cash needs. Meanwhile distress sales place the farmer in a poor bargaining position to gain good prices for their livestock, especially when many others are trying to sell animals at the same time, for example following crop failures after a flood event. Fishing in the river or trapping fish in water impoundments is a livelihood buffer for many residents.

\subsection{Water Accessibility and Management in Agriculture}

\subsubsection{Water Accessibility for Rice Growing}

Table 8. Season of growing rice in study sites

\begin{tabular}{lcc}
\hline \multirow{2}{*}{ Season Planting } & \multicolumn{2}{c}{ Farmer Response } \\
\cline { 2 - 3 } & Frequency & Percentage \\
\hline Rainy & 92 & 59.7 \\
Dry & 3 & 1.9 \\
Both & 58 & 37.7 \\
Non & 1 & 0.6 \\
Total & 154 & 100 \\
\hline
\end{tabular}

While rice production in the study communities is almost entirely rainfed, according the head village interviewed, several respondents in Thouat village could plant two rice crops by accessing irrigation. However, only $46 \%$ of 
the paddy area in the village (and just $0.7 \%$ of Taleo village)could be irrigated by pumping water from the river or ponds during the dry season, and the cost was higher than the benefit overall. Most farmers preferred not to plant during dry season and instead went to the provincial capital of Savannakhet or neighboring Thailand to find jobs.

3.4.2 Water Management in Agriculture

Table 9. Water management conditions in study sites

\begin{tabular}{lcc}
\hline \multirow{2}{*}{ Criteria } & Farmer Response \\
\cline { 2 - 3 } & Frequency & Percent \\
\hline Presence of irrigation program development & 94 & 61 \\
Yes & 59 & 38.3 \\
No & 153 & 99.4 \\
Total & 1 & 0.6 \\
Missing & 154 & 100 \\
Total & & \\
Why farmers do not find water storage methods & 5 & 3.2 \\
Non-Education & 22 & 14.3 \\
Don't know how to find the source & 73 & 47.4 \\
No answer & 18 & 11.7 \\
No budget & 33 & 21.4 \\
No water & 2 & 1.3 \\
Other & 153 & 99.4 \\
Total & & \\
Awareness of water harvesting & 115 & 74.7 \\
Yes & 39 & 25.3 \\
No & 154 & 100 \\
Total & &
\end{tabular}

According to interviews, irrigation expansion had been discussed in Thouat and Taleo villages since 2011, but no follow-up implementation had taken place until the time of the research, and farmers were not aware of any further information about the project. In Mouangkhai, no such work had been undertaken at the time of the research. According to the Irrigation Division of the Provincial Agriculture and Forestry Office, the project is under review and consideration for budget, and could commence in 2020. Table 9 also shows that $73 \%$ of respondents were unable to answer why they did not find water storage methods, indicating that no information or methods had been made accessible to the study sites before the period of the survey. However, after our explanation of water harvesting, 115 households or $74.5 \%$ of respondents stated awareness of water harvesting, and farmers indicated interest to participate in a program for this purpose.

3.5 Adaptation Strategies on Water Management for a Climate Change Resilient Community 
Table 10. Recommendations for adaptation strategies on water management and related factors

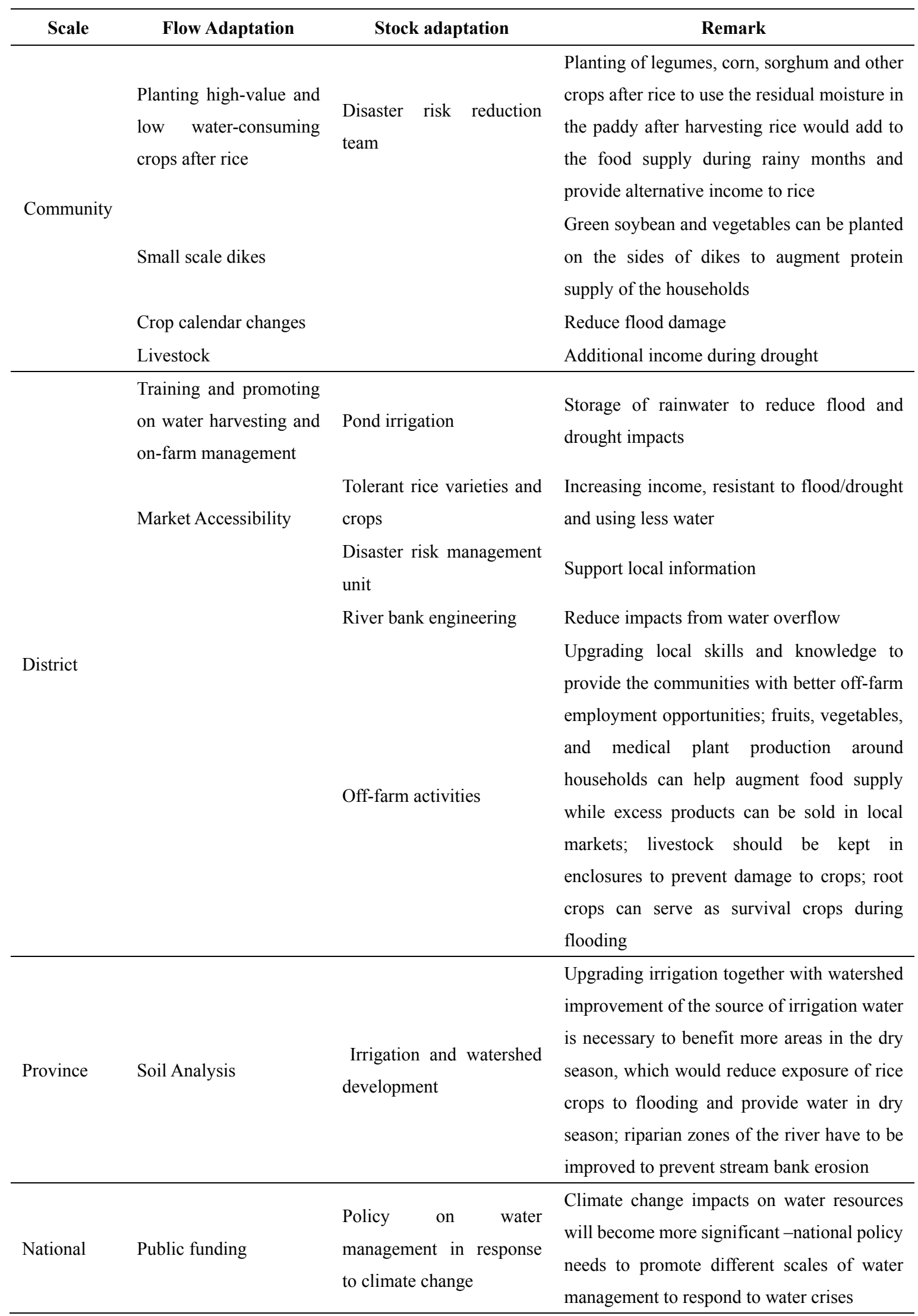

This study considers integrated flow and stock adaptation strategies (Agrawala et al, 2010) as necessary to 
increase resilience to climate change impacts in the three study villages. These are also part of different levels of adaptation at community, district, province and national scale, but focus on how people can manage water locally based on adaptive capacity and climatic conditions (Table 10). Flow adaptation covers shorter term options that are relatively cheap to put in place, and provide immediate benefits. Stock adaption requires higher investment for long-run benefits that might not be immediately felt by the community, and are instead preparing for major impacts of future climate change that have not happened yet. Higher confidence is therefore needed in the ability of stock adaptation options to cope with future climate risks than flow adaptations which adjust to current, immediate risks.

\section{Conclusion and Recommendations}

Hydrological, social and economic analyses have shown rice production in the study locations to be highly vulnerable to flooding, in combination with the difference in values of water balance calculations in the Xe Champhone river, to describe water conditions and management for agriculture in the dry season and rainy season in upstream, middle stream and downstream locations. Severe flooding usually occurred in September and October resulting in insufficient rice supply. Non-flood tolerant rice varieties remain in use, resulting in low or non-existent rice yields during the worst flooding. Meanwhile, the farms are rainfed and depend on the overflowing river for irrigation, hence the high sensitivity of the rice production system to extreme events. This sensitivity is both driven by and contributes to the socioeconomic vulnerability of the communities, lack of water for rice production in dry season and non-adaptation in terms of how to store water from the rainy season for use in dry season. Strengthening the climate change resilience of the communities in sustainable water management requires significant planning considerations at different scales, including the community, district, province and nation by a range of flow and stock adaptation options that should be considered in an integrated way to form local adaptation strategies.

\section{Recommendations}

Based on the results of this study, the recommendations for future research and development are as follows:

1) Promoting water harvesting for crops and vegetables to diversify planting rice in non-irrigated areas to improve income.

2) Research cropping systems after the rice harvest by planting high-value crops in elevated areas and around households to improve food supply.

3) Development of:

a) Disaster Risk Reduction Management and Climate Change Adaption (DRRM-CCA) committee in each village.

b) Watershed management to improve the source of irrigation water and irrigation system.

\section{Acknowledgements}

This research was supported by the University of Tsukuba and funded by the Japanese Government under the Monbukagakusho (MEXT) scholarship programme. The corresponding author wishes to convey appreciation and gratitude to the University of Tsukuba for supporting this research, and to partner institutions in Laos for their assistance in conducting the field study and coordinating with local communities and organizations. The authors thank the respondents for providing their time and insights on which this paper is based, and also our reviewers for their constructive contributions.

\section{References}

Adger, W. N., \& Barnett, J. (2009). Four reasons for concern about adaptation to climate change. Environment and Planning A, 4l(12), 2800-2805. http://journals.sagepub.com/doi/abs/10.1068/a42244

Aggarwal, P. K., \& Mall, R. K. (2002). Climate Change and Rice Yields in Diverse Agro-Environments of India. I. Evaluation of Impact Assessment Models. Retrieved from https://link.springer.com/content/pdf/10.1023\%2FA\%3A1013702105870.pdf

Bornales, R. G. (2004). Adaptation and vulnerability of Subanen community to the adverse environmental conditions in Mt. Malindang National Park, Philippines. Journal of Environmental Science \& Management, $7(1), 56$.

Boulidam, S. (2012). Simulation of Climate Change Impact on Lowland Paddy Rice Production Potential in Savannakhet Province, Laos. Retrieved from https://zidapps.boku.ac.at/abstracts/download.php?dataset_id=10413\&property_id=107 
Bradshaw, M. J., Abbott, A. J., \& Gelsthorpe, A. P. (1978). The Earth's Changing Surface. Wiley.

Department of Agriculture (DOA). (2015). Annual crop production statistics.

Hazarika, M. K., Bormudoi, A., Phosalath, S., Sengtianthr, V., \& Samarakoon, L. (2008). Flood Hazard In Savannakhet Province, Lao PDR Mapping Using Hec-Ras, Remote Sensing And Gis. Conference paper presented at 6th Annual Mekong Flood Forum, 27-28 May, 2008, Phnom Penh.

Hijioka, Y., Lin, E., Pereira, J. J., Corlett, R. T., Cui, X., Insarov, G. E., ... Surjan, A. (2014). Asia. In: Climate Change 2014: Impacts, Adaptation, and Vulnerability. Part B: Regional Aspects. Contribution of Working Group II to the Fifth Assessment Report of the Intergovernmental Panel on Climate Change [V. R. Barros, C. B. Field, D. J. Dokken, M. D. Mastrandrea, K. J. Mach, T. E. Bilir, ... L. L. White (Eds.)]. Cambridge University Press, Cambridge, United Kingdom and New York, NY, USA, pp. 1327-1370. Retrieved from https://www.ipcc.ch/pdf/assessment-report/ar5/wg2/WGIIAR5-Chap24_FINAL.pdf

IPCC. (2007). Climate Change 2007: Synthesis Report. Contribution of Working Groups I, II and III to the Fourth Assessment Report of the Intergovernmental Panel on Climate Change [Core Writing Team, Pachauri, R. K., \& Reisinger, A. (Eds.)]. IPCC, Geneva, Switzerland, 104 pp. Retrieved from https://www.ipcc.ch/pdf/assessment-report/ar4/syr/ar4_syr_full_report.pdf

IPCC. (2013). Climate Change 2013: The Physical Science Basis. Contribution of Working Group I to the Fifth Assessment Report of the Intergovernmental Panel on Climate Change [T. F. Stocker, D. Qin, G.-K. Plattner, M. Tignor, S. K. Allen, J. Boschung, ... P. M. Midgley (Eds.)]. Cambridge University Press, Cambridge, United Kingdom and New York, NY, USA, 1535 pp. Retrieved from https://www.ipcc.ch/pdf/assessment-report/ar5/wg1/WG1AR5_Frontmatter_FINAL.pdf

IPCC. (2014). Climate Change 2014: Synthesis Report. Contribution of Working Groups I, II and III to the Fifth Assessment Report of the Intergovernmental Panel on Climate Change [Core Writing Team, R. K. Pachauri, \& L. A. Meyer (Eds.)]. IPCC, Geneva, Switzerland, 151 pp. Retrieved from http://www.ipcc.ch/pdf/assessment-report/ar5/syr/SYR_AR5_FINAL_full_wcover.pdf

Kattel, R. R. (2015). Rainwater Harvesting And Rural Livelihoods In Nepal. SANDEE Working Paper No. 102$15 . \quad$ Retrieved from http://www.sandeeonline.org/uploads/documents/publication/1078_PUB_Working_Paper_102_Rishi.pdf

MRC Management Information Booklet Series No. 4, Impacts of Climate Change and National Institute of Disaster Management (NIDM) and Naational disaster Management Authority (NDMA). (2010). Handbook on Disaster Risk Management Mainstreaming in Development. Author. Islamabad. Retrieved March 15, 2013, from http://ndma.gov.pk/publiccations_One_UN_DRM/DRR\%20Mainstreaming/13_stardard_handbook_DRM_ Mainstreaming.pdf

MRC. (2010). Annual Mekong Flood Report 2009, Mekong River Commission, Office of the Secretariat in Phnom Penh, 80 pages. Retrieved from http://www.mrcmekong.org/assets/Publications/basin-reports/Annual-Mekong-Flood-Report-2009.pdf

Peng, S., Huang, J., Sheehy, J. E., Laza, R. C.,Visperas, R. M., Zhong, X., ... Cassman, K. G. (2004). Rice yields decline with higher night temperature from global warming. Proc. Natl. Acad. Sci. U.S.A. 101(27), 99719975. Retrieved from http://www.pnas.org/content/pnas/101/27/9971.full.pdf

Smit, B., Pilifosova, O., Burton I., Challenger, B., Huq, S., Klein, R. J. T., \& Yohe, G. (2001). Adaptation to climate change in the context of sustainable development and equity. In: Climate Change 2001: Impacts, Adaptation, and Vulnerability. Contribution of Working Group II to the Third Assessment Report of the Intergovernmental Panel on Climate Change [J. J. McCarthy, O. F. Canziani, N. A. Leary, D. J. Dokken, \& K. S. White (Eds.)]. Cambridge University Press, Cambridge, UK and New York, NY, USA, pp. 877-912. Retrieved from https://www.ipcc.ch/ipccreports/tar/wg2/pdf/wg2TARchap18.pdf

Tao, F., Hayashi, Y., Zang, Z., \& Sakamoto, T. (2007). Global warming, rice production, and water use in China: Developing a probabilistic assessment. Journal of Integrative Agriculture, 13(7), 1555-1564.

\section{Copyrights}

Copyright for this article is retained by the author(s), with first publication rights granted to the journal.

This is an open-access article distributed under the terms and conditions of the Creative Commons Attribution license (http://creativecommons.org/licenses/by/4.0/). 